\title{
Carbon Stock Analysis Along Altitudinal Gradient in Gedo Forest: Implications for Forest Management and Climate Change Mitigation
}

\author{
Hamere Yohannes ${ }^{1,}$, , Teshome Soromessa ${ }^{2}$, Mekuria Argaw ${ }^{2}$ \\ ${ }^{1}$ Department of Natural Resource Management, College of Agriculture and Natural Resource Science, Debre Berhan University, Debre \\ Berhan, Ethiopia \\ ${ }^{2}$ Center for Environmental Science, College of Natural Science, Addis Ababa University, Addis Ababa, Ethiopia
}

Email address:

hamerey@gmail.com (H. Yohannes)

\section{To cite this article:}

Hamere Yohannes, Teshome Soromessa, Mekuria Argaw. Carbon Stock Analysis Along Altitudinal Gradient in Gedo Forest: Implications for Forest Management and Climate Change Mitigation. American Journal of Environmental Protection. Vol. 4, No. 5, 2015 , pp. $237-244$. doi: 10.11648/j.ajep.20150405.14

\begin{abstract}
Forests provide important ecological and environmental benefits. They serve as natural sinker of atmospheric $\mathrm{CO}_{2}$ to mitigate climate change. In Ethiopia although, there is significant forest resource, the studies on carbon stock potential and factors that affect this potential have not been well studied. This study was done with the aim of estimating carbon stock potential and related factors that affect carbon sequestration in Gedo forest. Data was collected from $10 \mathrm{~m} \times 20 \mathrm{~m}$ plot along transect in systematically stratified forest part. The forest had total mean carbon stock of $523.64 \pm 29$ ton ha ${ }^{-1}$ with aboveground biomass $\left(281 \pm 23.34 \mathrm{t} \mathrm{C} \mathrm{ha}^{-1}\right)$ and belowground biomass $\left.56.1 \pm 4.66 \mathrm{t} \mathrm{C}^{-1}\right)$, litter biomass $(0.41 \pm 0.008 \mathrm{t} \mathrm{C}$ ha $\left.{ }^{1}\right)$, deadwood biomass $\left(2.37 \pm 1.33 \mathrm{t} \mathrm{C} \mathrm{ha}^{-1}\right)$ and soil organic carbon $\left(183.69 \pm 6.17 \mathrm{t} \mathrm{C} \mathrm{ha}^{-1}\right)$. Spatial distribution of the carbon stock varied along environmental gradient. Altitude has inverse relation with aboveground biomass, belowground biomass, deadwood carbon and total carbon density. Altitude also has significant effect on all carbon pool except litter biomass and soil organic carbon. More aboveground biomass, belowground biomass and total carbon were found in the middle altitude and lower carbon was found in the upper altitude. Soil organic carbon and litter biomass carbon decreases with altitude. Deadwood biomass carbon pool was found only in lower altitude. Based on overall result it is concluded carbon sequestration in a forest ecosystem is determined by altitudinal gradient.
\end{abstract}

Keywords: Altitudinal Gradient, Biomass Carbon, Climate Change, Gedo Forest, Soil Organic Carbon

\section{Introduction}

One of the greatest environmental issues facing modern society is global climate change. This change is very likely a result of rising atmospheric concentrations of anthropogenic greenhouse gases (GHGs) such as carbon dioxide $\left(\mathrm{CO}_{2}\right)$, methane $\left(\mathrm{CH}_{4}\right)$, nitrous oxide $\left(\mathrm{N}_{2} \mathrm{O}\right)$, and certain fluoride compounds [1]. There is strong evidence that warming of the earth over the last half-century has been caused largely by human activities for instance burning of fossil fuels, urbanization and change in land use, including agriculture and deforestation [2].

Forests play an important role in global carbon (C) cycle because they store large quantities of $\mathrm{C}$ in vegetation and soil, exchange $\mathrm{C}$ with the atmosphere through photosynthesis and respiration particularly primary forest [3] However, the vegetation has undergone destruction and degradation in the modern times due to human intervention like deforestation and degradation. This intervention has resulted in emission of carbon in the ecosystem. Therefore, there is a need to address environmental issues related to this. According to [4], despite role of forest, little attempts have been made to organized study that shows forest potential in carbon stock in developing countries. This is true in Ethiopia, where there is a significant forest resource but these resources are not well addressed and managed. Ethiopia forest cover was about 420,000 square kilometers (35\% of Ethiopia's land) during twentieth century. These forest cover have declined to $16 \%$ in $1952,3.6 \%$ by $1980,2.6 \%$ by 1987 , and an estimated $2.4 \%$ in 1992 [5]. The recent study shows less than $14.2 \%$ of the forest of the entire country is covered with trees. The current forests resources of Ethiopia store 2.76 billion tons of carbon in the 
aboveground biomass, which will be released to the atmosphere in 50 years if the deforestation continues at the present rate of about $2 \%$ [6]. Forest management, therefore, has the potential to mitigate climate change [7].

In Ethiopia there has been very limited forest carbon stock study by considering environmental factors that affect carbon stock. Therefore, this study was done to assess and correlate the environmental variable with carbon amount. And this gives basic information for the management of the forest to mitigate climate change.According to [8], In Gedo forest there is severe human intervention problem and it was intact but now it is depleted and the existing conditions call for a critical mitigating means. To get considerable attention, one way could be show its role in different perspective like its potential to sequester carbon. This has a contribution to control global warming as well as it will have a benefit for the community and country through carbon trade if it is well protected. And in Gedo forest no such study has been conducted with the aim of assessing its carbon stock amount and its dynamics along altitudinal gradient.

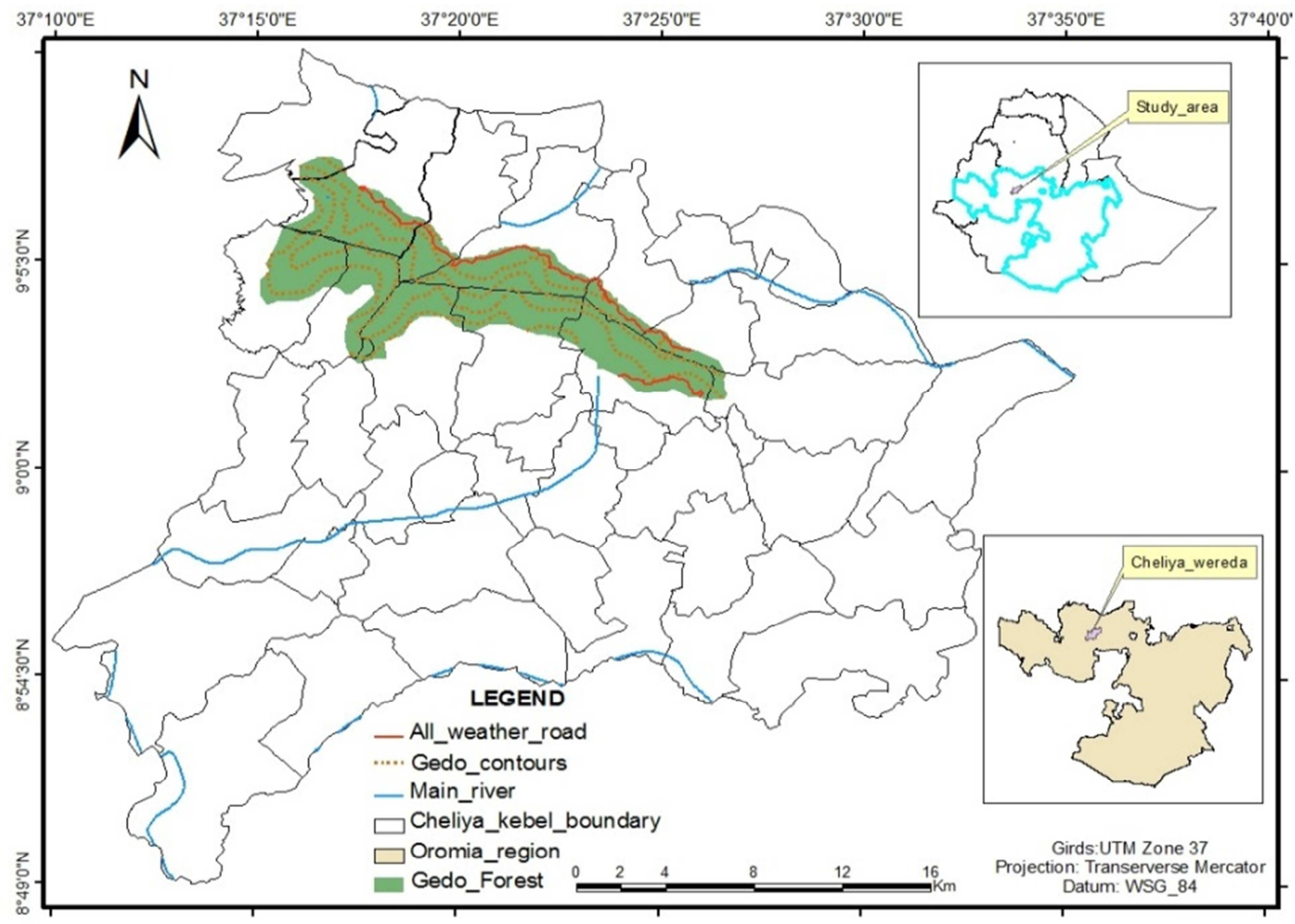

Figure 1. Map of the study area.

The annual mean temperature of study area ranges from $11^{\circ} \mathrm{C}$ to $19^{\circ} \mathrm{C}$ with a mean of $15^{\circ} \mathrm{C}$. According to National Meteorological Services Agency data obtained for Gedo area, annual rainfall in the forest area is between $500 \mathrm{~mm}$ and $1500 \mathrm{~mm}$ and has mean annual rainfall of $1054 \mathrm{~mm}$.Gedo

\section{Materials and Methods}

\subsection{Description of the Study Area}

This study was conducted in Cheliya District, West Shewa Zone of Oromia National Regional State. The district has altitudinal range of 1300-3060m a.s.1 [9]. Gedo Forest lies approximately between latitudes $9^{0} 01^{`}$ and $9^{0} 09^{`}$ North and longitudes $37^{\circ} 15^{`}$ and $37^{\circ} 27^{`}$ East (Figure 1). The natural forest of the area is estimated to be the continuation of Jibat regional forest priority area in the southwest which is part of tropical rain forest. Gedo forest is legally demarcated in 1994. It is one of the national forest priority areas of Ethiopia. It covers the total area of above 10,000 hectare [10]. On the other hand, according to Oromia Forest and Wildlife Enterprise Office, based on recent survey the natural forest area is estimated about 5,000 ha excluding settlement, farmland, grazing land and bare land. 
also the forest includes about five hundred hectare of plantation such as Acacia melanoxylon, Eucalyptus spp, Grevillea robusta, Juniperus procera, Jacaranda mimosifolia and Pinus patula [8].

\subsection{Methodology}

\subsubsection{Delineation and Stratification of Study Area}

The spatial boundaries of the study area were clearly defined and properly recognized to facilitate accurate measuring, accounting and verification. GPS tracking were used for boundary delineation. Then stratification was done based on altitudinal variation to obtain homogenous units, this increase the precision of measuring and estimating carbon stock without increasing the cost improperly. At the end, the study site classify into three stratum: Lower altitude (2279m - 2420m); Middle altitude (2421m - 2549m) and higher altitude $(>2550 \mathrm{~m})$.

\subsubsection{Sampling Techniques and Field Measurement}

In this study, transect approach was applied for tree sampling and measurement. Sampling sites fromthe forest were arranged by the line transects at an interval from the bottom, middle and at thetop of the forest. A plot of $10 \mathrm{~m} \mathrm{x}$ $20 \mathrm{~m}\left(200 \mathrm{~m}^{2}\right)$ was systematically set 200 meter gap betweeneach plot and the location of the plot were recorded.Trees above and equal to $5 \mathrm{~cm}$ in $\mathrm{DBH}$ within sample plots were measured by using diameter tape. Five smaller sub plot of 1 square meter in size were established at the center and at corner of each plot to collect leaf litter and soil. Together with field tree vegetation measurement the location of each plot including altitude was recorded by GPS. In order to identify measured tree species; a complete list of trees in each plot was done. Plant Specimens were collected, pressed, dried then identified at National Herbarium of Addis Ababa University using specimens in the Herbarium and published of Flora of Ethiopia and Eritrea.

\section{Field Carbon Stock Measurement}

Aboveground Tree Biomass (AGB): The DBH (at $1.3 \mathrm{~m}$ ) of individual trees greater than or equal to $5 \mathrm{~cm} \mathrm{DBH}$ were measured in each rectangular plot, and marking each tree to prevent repetition.

Leaf litter biomass: Five 1 square meter sub plot of in size were established at the center and each corner of eachplot. The leaf litter within the $1 \mathrm{~m}^{2}$ sub plots were collected and weighed. Hundred grams of evenly mixed sub-samples were brought to the laboratory placing in a sample plastic bag to determine moisture content, from which total dry mass and organic matter can then be calculated [11].

Dead Wood Biomass: According to [12], if a stump is taller than $1.3 \mathrm{~m}$ and branched, it wasmeasured in the same way as standing live trees. If it is less than $1.3 \mathrm{~m}$ tall, the diameter andheight was measured as close as possible to the top and considered as logged trees. Therefore, deadwood trees were measured and recorded on separate data sheet.

Soil Organic Carbon (SOC): Soil samples for soil carbon determination were collected at the same sampling subquadratsrecommended for litter sampling. From the center and corner of each plot a pits of up to $30 \mathrm{~cm}$ in depth were dug to best represent forest. Hundred grams of composite sample werecollected from one plot from three depths (0-10 $\mathrm{cm}, 10-20 \mathrm{~cm}$ and $20-30 \mathrm{~cm}$ ) by digging thesoil with the help of standardized 100 or $300 \mathrm{~cm}^{3}$ metal soil sampling auger. The soil samplescollected from plot were brought to the laboratory placing in a sample paper bags with itslabel. Individual soil sample was taken by core sampler to estimate bulk density.

Carbon Estimation at Each Pool

Above Ground Biomass (AGB) carbon stock

The equation to be used to calculate the above ground biomass is given below:

$$
\mathrm{Y}=34.4703-8.0671(\mathrm{DBH})+0.6589\left(\mathrm{DBH}^{2}\right)
$$

Where, $\mathrm{Y}$ is above ground biomass in $\mathrm{kg}$., $\mathrm{DBH}$ is diameter at breast height in $\mathrm{cm}$.

The carbon content in the biomass were estimated by multiplying 0.47 while multiplication factor 3.67 needs to be used to estimate $\mathrm{CO}_{2}$ equivalent [12].

Below Ground Biomass (BGB) carbon stock

The equation developed by [13], to estimate below-ground biomass was used.

The equation is given below:

$$
\mathrm{BGB}=\mathrm{AGB} \times 0.2
$$

Where, BGB is below ground biomass, AGB is above ground biomass, 0.2 is conversion factor (or $20 \%$ of AGB).

Leaf litter Biomass carbon stock

According to [12], estimation of the amount of biomass in the leaf litter can be calculated by:

$$
\mathrm{LB}=\frac{W \text { field }}{A} \times \frac{\text { Wsub-sample }(\text { dry })}{\text { Wsub-sample }(\text { before dry })} \times \frac{1}{10,000}
$$

Where: LB $=$ Litter (biomass of litter t ha-1);

$\mathrm{W}$ field $=$ weight of wet field sample of litter sampled within an area of size $(\mathrm{g})$;

$\mathrm{A}=$ size of the area in which litter were collected (ha);

$\mathrm{W}$ sub-sample, dry = weight of the oven-dry sub-sample, and

W sub-sample, before dry = weight of the fresh subsample of litter taken to the laboratory to determine moisture content $(\mathrm{g})$.

Then Carbon stocks in dead litter biomass calculated by:

$$
\mathrm{CL}=\mathrm{LB} \times \% \mathrm{C}
$$

Where, $\mathrm{CL}$ is total carbon stocks in the dead litter in $\mathrm{t} \mathrm{ha}^{-1}, \%$ $\mathrm{C}$ is carbon fraction determined in the laboratory [12].

Dead Wood biomass carbon stock

Standing dead wood carbon

The total amounts of biomass found in dead wood were measured based on the types of dead wood. For standing dead wood which have branches were measured similar to the biomass estimation allometric equation of above ground biomass. When standing dead wood have not leaves, there was a subtraction of 5-6 percent for softwood/ conifer species and 2-3 percent of hardwood/broadleaved species for 
their branches [12]. Most of the existing species were conifer species, and hence 5-6 percent reduction from the total above ground biomass of each tree provided estimates of the dead wood carbon stock. The allometric equation confirmed in REDD methodology (2009) were used to estimate the amount of biomass in standing dead wood.

$$
\mathrm{BSDW}=\Sigma \Sigma \prod_{i}^{n}={ }_{0} \frac{1}{3}\left(\frac{D}{200}\right)^{2} h \times s
$$

Where, biomass is expressed in $\mathrm{kg}, \mathrm{h}=$ length $(\mathrm{m}), \mathrm{D}=$ tree diameter $(\mathrm{cm})$ and $\mathrm{s}=$ specific gravity $\left(\mathrm{g} \mathrm{cm}^{-3}\right)$ of wood. According to[14], specific gravity $\left(\mathrm{g} \mathrm{cm}^{-3}\right)$ of woodis estimated as $0.5 \mathrm{~g} \mathrm{~cm}^{-3}$ as default value.

Then the total biomass of dead wood were obtained by adding the biomass of standing dead woodwhich have branch and standing biomass of wood which have no branch.

$$
\mathrm{TBDW}=\mathrm{SBDWB}+\mathrm{SBDWN}
$$

Where: $\mathrm{TBDW}=$ Total Biomass Dead Wood

SBDWB $=$ standing biomass dead wood branched

SBDWN = standing biomass dead wood non branched

Then the carbon content in dead wood is calculated by multiplying total biomass of dead wood with the [15] default carbon fraction of 0.47 .

\section{Soil Organic Carbon}

According to[12], soil organic carbon estimated by the formula:

$$
\mathrm{SOC}=\mathrm{BD} * \mathrm{~d} * \% \mathrm{C}
$$

Where, $\mathrm{SOC}=$ soil organic carbon stock per unit area (t ha$1), \mathrm{BD}=$ soil bulk density $(\mathrm{g} \mathrm{cm}-3)$,

$\mathrm{D}=$ the total depth at which the sample was taken $(30 \mathrm{~cm})$, and

$\% \mathrm{C}=$ Carbon concentration $(\%)$.

Total Carbon Stock Density

The carbon stock density is calculated by summing the carbon stock densities of the individual carbon pools using the [12] formula;

Carbon stock density of a study area:

$\mathrm{C}$ density $=\mathrm{CAGB}+\mathrm{CBGB}+\mathrm{C} \mathrm{Lit}+\mathrm{CDWD}+\mathrm{SOC}$ (equ.8)

Where:

$\mathrm{C}$ density $=$ Carbon stock density for all pools $\left[\mathrm{t} \mathrm{C} \mathrm{ha}^{-1}\right]$

$\mathrm{C}_{\mathrm{AGB}}=$ Carbon in above -ground tree biomass $\left[\mathrm{t} \mathrm{C} \mathrm{ha}^{-1}\right]$

$\mathrm{C}_{\mathrm{BGB}}=$ Carbon in below-ground biomass $\left[\mathrm{t} \mathrm{C} \mathrm{ha}^{-1}\right]$

$\mathrm{C}_{\mathrm{Lit}}=$ Carbon in dead litter $\left[\mathrm{t} \mathrm{C} \mathrm{ha}{ }^{-1}\right]$
$C_{\text {DWD }}=$ Carbon in dead wood biomass $\left[\mathrm{t} \mathrm{C} \mathrm{ha}^{-1}\right]$

$\mathrm{SOC}=$ Soil organic carbon $\left[\mathrm{t} \mathrm{C} \mathrm{ha}^{-1}\right]$

The total carbon stock is then converted to tons of $\mathrm{CO}_{2}$ equivalent by multiplying it by $44 / 12$ or 3.67 [12].

Data analysis

After data collection was completed, data analysis of various carbon pools measured in theforest was accomplished. The data obtained from $\mathrm{DBH}$, fresh weight and dry weight of litter, dead wood and soil were analyzed by using Statistical Package for Social Science (SPSS) software version 20.The significant of measured parameter were tested by one way ANOVA and post-hoc test at $\alpha$ of 0.05 to perform pairwise comparison of means and yield significant results. Pearson correlation was used to test the relationship between forest carbon stocks with altitude.

\section{Results and Discussion}

\subsection{Results}

\section{Carbon stock at each pool}

As shown in table 1, the average carbon stock per plot for aboveground carbon pool was $281 \pm 23.34$ ton ha ${ }^{-1}$ with $\mathrm{CO}_{2}$ equivalent of $1031.2 \pm 85.68$ ton $\mathrm{ha}^{-1}$. The average belowground carbon stock was calculated as $56.19 \pm 4.66$ ton ha $^{-1}$ with $\mathrm{CO}_{2}$ equivalent of $206.24 \pm 17.13$ ton $\mathrm{ha}^{-1}$. The mean carbon stock in leaf litter biomass calculated as $0.41 \pm$ 0.008 ton $\mathrm{ha}^{-1}$. In this forest, a few deadwoods were observed in few plots as a result very small standing deadwood biomass and carbon storage was calculated. The dead wood carbon pool accounts only standing dead wood which were branched trees, non-branched trees and logged trees. The total carbon stock mean in deadwood was calculated as $2.37 \pm 1.33$ ton $\mathrm{ha}^{-1}$. Likewise the total mean soil carbon storage calculated as $183.69 \pm 6.17$ ton $\mathrm{ha}^{-1}$. The total mean carbon storage of this forest was $523.64 \pm 29$ ton $\mathrm{ha}^{-1}$.

The aboveground biomass comprised 53\%, belowground biomass comprised $11 \%$, Leaf litter biomass comprised $0.07 \%$, and deadwood biomass holds $0.45 \%$ and Soil comprised $35.5 \%$ carbon within their biomass. The largest stocks was observed on aboveground biomass followed by soil carbon pool, belowground biomass, deadwood biomass carbon storage lastly leaf litter biomass carbon. In general, the aboveground part comprises the total of $53.52 \%$ and belowground part takes $46.48 \%$ (Table 1 ).

Table 1. Summary mean of carbon density (ton $\left.\mathrm{ha}^{-1}\right)$ and distribution of each pool (\%).

\begin{tabular}{lllllll}
\hline & Carbon pools & & & & \\
\cline { 2 - 7 } & AGBC & BGBC & LBC & DWDBC & SOC & Total.C \\
\hline Mean(ton ha1) & $281 \pm 23.34$ & $56.1 \pm 4.66$ & $0.41 \pm 0.008$ & $2.37 \pm 1.33$ & $183.69 \pm 6.17$ & $523.64 \pm 29$ \\
Percentage & 53 & 11 & 0.07 & 0.45 & 35.5 & 100 \\
\hline
\end{tabular}

AGBC and BGBC (Above ground and belowground biomass carbon respectively; LBC (Letter Biomass Carbon); DWDBC (Dead wood Biomass Carbon); SOC (Soil Organic Carbon) and T.C (Total Carbon)

Carbon stock at each pool with Altitudinal gradient In this study, it was observed that carbon stock amount at each pool show variation with altitudinal variation. As shown in table 2 below, it was observed that the middle altitudinal 
range takes the larger portion of carbon account for both $\mathrm{AGB}$ and BGB which have mean total of $324.05 \pm 36.68$ ton $\mathrm{ha}^{-1}$ and $64.81 \pm 7.33$ ton $\mathrm{ha}^{-1}$, respectively. The higher altitudinal range takes lowest portion of carbon stock with $127.78 \pm 30.81$ ton $\mathrm{ha}^{-1}$ mean total carbon account in AGB and $25.55 \pm 6.1$ ton $\mathrm{ha}^{-1}$ in BGB. Similarly, the higher carbon stock in litter biomass carbon and SOC was estimated at lower altitudinal range of mean $\left(0.55 \pm 0.011\right.$ ton $^{-1}$ and $185 \pm 13.6$ ton $\left.\mathrm{ha}^{-1}\right)$ and lower amount was found in higher altitude $\left(0.35 \pm 0.04\right.$ ton $\mathrm{ha}^{-1}$ and $182 \pm 8.74$ ton $\left.\mathrm{ha}^{-1}\right)$. Dead wood biomass carbon mean computed as $7.12 \pm 3.89$ ton ha $^{-1}$ and only found in lower altitude. Based on the total carbon stocks the rank was ordered as middle altitude $>$ lower altitude $>$ higher altitude.

Table 2. Estimated carbon stock (ton $\mathrm{ha}^{-1}$ ) along altitudinal variation at each carbon pools.

\begin{tabular}{lllllll}
\hline Elevation & C.AGB & C.BGB & C.LB & C.DWDB & C.OS & Total Carbon \\
\hline Lower & $296.89 \pm 34.27$ & $59.37 \pm 6.85$ & $0.55 \pm 0.011$ & $7.12 \pm 3.89$ & $185 \pm 13.6$ & $545.80 \pm 42.09$ \\
Middle & $324.05 \pm 36.68$ & $64.81 \pm 7.33$ & $0.41 \pm 0.04$ & 0 & $184.37 \pm 10.14$ & $573 \pm 45.94$ \\
Higher & $127.78 \pm 30.81$ & $25.55 \pm 6.1$ & $0.35 \pm 0.04$ & 0 & $182 \pm 8.74$ & $338.69 \pm 41.21$ \\
\hline
\end{tabular}

Based on one way ANOVA analysis, altitude has significant effect in aboveground biomass carbon (F-Value $=5.172, \mathrm{P}$-value $=.008)$, belowground biomass carbon $(\mathrm{F}-$ Value $=5.173$, P-value $=.008)$, deadwood biomass carbon $(\mathrm{F}$ Value $=3.354$, P-value $=.040$ ) and total carbon (F-Value $=4.779, \mathrm{P}$-value $=.011)$ and post hoc test was indicate that the mean difference was significant at $\alpha$ of 0.05 (table 3 ).

Table 3. Summary of significant value of altitude on different carbon pool.

\begin{tabular}{llll}
\hline Parameter & Carbon pools & F-Value & P-Value \\
\hline & C.AGB & 5.172 & $.008^{*}$ \\
& C.BGB & 5.173 & $.008^{*}$ \\
Altitude gradient & C.LB & 2.851 & .064 \\
& C.DWDB & 3.354 & $.040^{*}$ \\
& SOC & .019 & .981 \\
& Total C. & 4.779 & $.011^{*}$ \\
\hline
\end{tabular}

*the effect is significant at the $\mathrm{p}<0.05$ level

\section{Correlation of carbon stock with altitude}

In order to know their relation, correlation can be mostly applied statistical analysis method. It shows significant, extent and direction of the relationship. AGB and BGB carbon shows weak inverse relation with elevation $(\mathrm{R}=-.287$; $\mathrm{P}=.012$ ) at $\alpha$ of 0.05 . Deadwood biomass and total carbon also shows negative weak correlation with altitude $(R=-.264$; $\mathrm{P}=.022$ and $\mathrm{R}=-259 ; \mathrm{P}=0.025)$ at $\alpha$ of 0.05 . On the other hand, Litter biomass and SOC shows no correlation with altitude (table 4).

Table 4. Summary of correlation of carbon pools and altitude.

\begin{tabular}{llll}
\hline Parameter & Carbon pools & R-Value & P-Value \\
\hline \multirow{5}{*}{ Elevation gradient } & C.AGB & $-.287^{*}$ & .012 \\
& C.BGB & $-.287^{*}$ & .012 \\
& C.LB & -.106 & .364 \\
& C.DWDB & $-.264^{*}$ & .022 \\
& SOC & -.140 & .230 \\
& Total C. & $-.259^{*}$ & .025 \\
\hline
\end{tabular}

* Correlation is significant at the 0.05 level (2-tailed).

\subsection{Discussion}

The average AGB carbon in Gedo forest (281 $\left.\mathrm{t} \mathrm{C} \mathrm{ha}^{-1}\right)$ was much more than that of previous estimates about 45.45 $\mathrm{t} \mathrm{C} \mathrm{ha}{ }^{-1}$ for forests of Ethiopia [16], and 193.64 $\mathrm{t} \mathrm{C} \mathrm{ha}^{-1}$ for evergreen forest [23]. 143 ton $\mathrm{ha}^{-1}$ carbon for all types of forest for all sub-Saharan Africa $[16,17]$; 73t $\mathrm{C} \mathrm{ha}^{-1}$ for tropical dry forest [15] and $58.9 \mathrm{t} \mathrm{C} \mathrm{ha}^{-1}$ for eastern and southern Africa forests [18].Gedo forest was also compared with other Dry Evergreen Afromontane forests of Ethiopia (Egdu forest, Chilimo forest, Menagesha Suba state forest and Danaba community forest) based on similarities in agro ecological condition and species composition for their carbon storage capacity (table 5). The AGB and BGB carbon mean of the present study was more than all compared forests and close to Danaba community forest mean result. The large AGB carbon density can be related with the presence of higher density of trees which are more productive and species diversity. This clearly indicated that Gedo forest has better stem size as well as carbon stock because carbon content is directly related to biomass, i.e. the higher the biomass the greater the carbon.Despite this forest has human interference till it has good potential. This suggestion supported by [8].

The mean carbon stock in present study for leaflitter biomass ( 0.41 ton $\mathrm{C} \mathrm{ha}^{-1}$ ) was less as compared to other forests except Chilimo forest and also very low from previous estimated (2.52-3.69 $\left.\mathrm{t} \mathrm{C} \mathrm{ha}^{-1}\right)$ for dry tropical forests [19],(1.58 $\left.\mathrm{t} \mathrm{ha}^{-1}\right)$ for evergreen forest [20], (1.4-4.8 t $\mathrm{C} \mathrm{ha}{ }^{-1}$ ) for tropical and sub-tropical forest [21]. Litterfall biomass accumulation may associated with forest stand condition such as stand properties (kind of species and diversity of stand, basal area, canopy cover, density of trees) and climate [22]. Similarly, according to [23], tropical forests show higher rate of decomposition because of climatic condition. Therefore, the present study of low amount of litter fall might be due to mainly decomposition rate and stand properties like species type and canopy cover.

SOC amount of the present study (183.69 ton ha ${ }^{-1}$ ) was greater than Chilimo and Menagesha Suba state forest but lower than Danaba community forest and Egdu forest (Table 5), This value also high as compared to $\left(55 \mathrm{t} \mathrm{C} \mathrm{ha}^{-1}\right)$ for tropical forest soil [24] but lower (209.54 $\left.\mathrm{t} \mathrm{C} \mathrm{ha}^{-1}\right)$ for evergreen forest [20].The present study area SOC stock amount may be due to climatic condition, amount of soil 
organic matter and canopy cover.

Table 5. Comparison of carbon stock (ton ha ${ }^{-1}$ ) of the present study with other similar studies.

\begin{tabular}{lllllll}
\hline \multirow{2}{*}{ Study site } & Carbon pools & & & & & \\
\cline { 2 - 6 } & AGBC & BGBC & LBC & DWDC & SOC & \multicolumn{2}{c}{ Total C. mean } \\
\hline Gedo forest $^{1}$ & 281 & 56.1 & 0.41 & 2.37 & 183.69 & 523.6 \\
Egdu forest $^{2}$ & 278.08 & 55.62 & 3.47 & - & 277.56 & 614.72 \\
Chilimo Forest $^{3}$ & 90.25 & 17.32 & 0.386 & - & 109.40 & 218.01 \\
Menagasha Suba State Forest $^{4}$ & 133 & 26.99 & 5.26 & 6.34 & 121.28 & 292.87 \\
Danaba community forest $^{5}$ & 270.03 & 41.76 & 1.06 & - & 186.40 & 507.29 \\
\hline
\end{tabular}

Source: ${ }^{1}$ Present study $(2015),{ }^{2}[25],{ }^{3}[26],{ }^{4}[27],{ }^{5}[28]$.

\section{Carbon stocks variation along altitudinal gradient}

In present study, all carbon pool result was varied within altitudinal gradient. Altitude has significant difference and inverse correlation with all carbon pools except litter biomass and soil organic carbon. This result consistent with [29] found that negative correlation of tree biomass with altitude. Similarly, in other studies it has been reported that biomass carbon storage decreases as altitude increases [30, 31]. On the other hand, it has been reported by many studies as live biomass carbon increase with altitude increases [25, 32, 33]. In the present study, the middle altitude takes the most AGB and BGB carbon storage and much more depleted carbon storage observed on higher altitude, this result consistent with [34]. Based on the mean result, relatively it is possible to say as altitude decreases biomass carbon increases. According to [19, 35], large individual trees account more carbon proportion. Similarly for the present study, the reason might be related with the presence of more productive stem density in the middle altitude than in higher altitude.

Though [34] study found that deadwood biomass carbon in all altitude classes with more carbon stock in middle altitude, the present study, reported that deadwood biomass carbon found only in lower altitude. Deadwood biomass carbon found only in lower altitude. This is related with more of logged and standing dead wood was foundin the lower altitude. And in the higher altitude, this carbon pool was not found. This might be related to in study area; it seems difficult to collect wood in the higher altitude with steep slope.

Although in many studies it was reported that as altitude increase SOC and LB carbon increases [21, 36, 37]. In present study, it was observed that SOC and Litter biomass means decreases as altitude increases. This result was consistent with [31, 35, 38]. According to [38], Forest stand with dense canopy and higher input of litter can results in maximum storage of carbon stock in the pool. Consequently, the present study area of decreasing trend in SOC stock along elevation might be due to canopy cover, litter biomass accumulation and species diversity. The overall trend of total means carbon stock of the forest show similar pattern with AGB and BGB carbon. This might be due to the fact that total carbon density mostly depending on aboveground biomass carbon pool.

\section{Conclusion}

Carbon stock study of forests is crucial to show forest potential and role to mitigate climate change risk. Forests have a capability to store substantial amount of carbon within their biomass and soil. Forest carbon stock can influence by different factors such as natural factors, environmental factors, physical factors and human disturbances. This study has shown that forest carbon stock is affected by one of environmental variables i.e. altitude. Each carbon pool shows variation along this environmental gradient. And altitude plays a key role in both aboveground and belowground carbon pool account. This is related with the distribution of productive stem density within the forest.

\section{References}

[1] IPCC. (2007). Synthesis Report. 52 p. Fourth Assessment Report. Both of these IPCC publications synthesize information from all Working Groups: WG I--The Physical Science Basis; WG II -- Impacts, Adaptation, and Vulnerability; WG III-Mitigation of Climate Change. Download from: http://www.ipcc.ch/pdf/assessment-report/ar4/syr/ar4_syr.pdf.

[2] Samalca, K. I., Gier, D. L. and Ali, H. (2009). Estimation of tropical forest biomass for assessment of carbon sequestration using regression models and remote sensing. Berua, East Calimantan: Indonesia.

[3] McMahon, S. M., Parker, G. G. and Miller, D. R. (2010). Evidence for a recent increase in forest growth. Proceedings of the National Academy of Sciences.J. Science107: 3611-3615.

[4] Ravindranath, N. H., Chaturvedi, R. K. and Murthy, I. K. (2008). Forest conservation, Afforestation and reforestation in India: Implications for forest carbon stocks. Curr. Sci., 95 (2): 216222.

[5] Federal Democratic Republic of Ethiopia. (1998). National Action Programme to Combat Desertification.Vol. I: The State of Natural Resources in Arid, Semi-Arid and Dry SubHumidAreas. EPA 1998 report, Addis Ababa, Ethiopia, Pp. 2835.

[6] Yitebitu Moges, Zewdu Eshetu and Sisay Nune. (2010). A review on Ethiopian Forest Resources: current status and future management options in view of access to carbon finances. Prepared for the Ethiopian climate research and networking and the United Nations development programme (UNDP). Addis Ababa, Ethiopia. 
[7] Bonan, G. (2008). Forests and climate change: Forcing, feedbacks, and the climate benefits of forests. J. Science320: 1444-1449.

[8] Birhanu Kebede, Teshome Soromessa and Ensermu Kelbessa. 2014. Structure and Regeneration Status of Gedo Dry Evergreen Montane Forest, West Shewa Zone of Oromia National Regional State, Central Ethiopia. Sci. Technol. Arts Res. J., April-June 2014, 3(2): 119-131.

[9] Endalew Amenu. (2007). Use and management of medicinal plants by indigenous people of Ejaji area (CheliyaWoreda) West Shoa, Ethiopia: an ethno botanical approach. Unpublished M.Sc. Thesis, Addis Ababa University, Addis Ababa.

[10] Young, J. (2012). Ethiopian Protected Areas a 'Snapshot. A reference guide for future strategic planning and project funding: Ethiopia.

[11] Bhishma, P. S., Shiva, S. P., Ajay, P., Eak, B. R., Sanjeeb, B., Tibendra, R. B., Shambhu, C., and Rijan, T. (2010). Forest Carbon Stock Measurement: Guidelines for measuring carbon stocks incommunity-managed forests. Funded by Norwegian Agency for Development Cooperation (NORAD).Asia Network for Sustainable Agriculture and Bioresources (ANSAB) publishing, Kathmandu, Nepal, pp.17-43.

[12] Pearson, T. R., Walker, S. and Brown, S. 2005. Sourcebook for land-use, land-use change and forestry projects. Winrock International and the Bio-carbon fund of the World Bank. Arlington, USA, pp. 19-35.

[13] MacDicken, K. G. (1997). A Guide to Monitoring Carbon Storage in Forestry and Agro-forestry Projects. In Forest Carbon Monitoring Program. Winrock International Institute for Agricultural Development, Arlington, Virginia.

[14] Hairiah, K., Sitompul, S. M., Noordwijk, M. and Palm, C. (2001). Methods for sampling carbon stocks above and below ground. International Centre for Research in Agroforestry. Southeast AsianRegional Research Programme, Bogor, Indonesia, pp. 1015 .

[15] IPCC. (2006). Good practice guidelines for National Greenhouse gas inventories. Switzerland: Intergovernmental panel on climate change. Unpublished document.

[16] Brown, S. 1997. Estimating biomass and biomass change of tropical forests: A primer Rome, Italy, Food and Agriculture Organization of the United Nations (FAO).

[17] Gibbs, H, K. and Brown, S. (2007).Geographical distribution of woody biomass carbon stocks in tropical Africa: an updated database for 2000 .

[18] IPCC. (2010). Global Forest Resources Assessment 2010 Main report. FAO. Forestry Paper. 163. Food and Agriculture Organization of the United Nations: Rome.

[19] Brown, S. and Lugo, A. (1982). The storage and production of organic matter in tropical forests and their role in the global carbon cycle. Biotropica14: 161-187.

[20] Mohanraj, R., Saravanan, J., Dhanakumar, S. (2011). Carbon stock in Kolli forests, Eastern Ghats (India) with emphasis on aboveground biomass, litter, woody debris and soils. J. Forest. 4: 61-65.

[21] Chang, C., Wang, C., Chou, C., Duh C. (2010). The Importance of Litter Biomass in Estimating Soil Organic Carbon Pools in Natural Forests of Taiwan. Taiwan Journal of Science. 25(2): 171-80.
[22] De Castilho, C. V., Magnusson, W. E., de Araújo, R. N. O., Luizão, R. C. C., Luizão, F. J., Albertina, P., Higuchi, N., 2006. Variation in aboveground tree live biomass in a central Amazonian Forest: effects of soil and topography. J. Forest Ecology Management. 234: 85-96.

[23] Salinas, N. Malhi1, Y. Meir, P. Silman, M. Roman Cuesta, R. Huaman, J. Salinas, D. Huaman, V. Gibaja, A. Mamani, M. and Farfan, F. (2010). The sensitivity of tropical leaf litter decomposition to temperature: results from a large-scale leaf translocation experiment along anelevation gradient in Peruvian forests. New Phytologist. 10 (1111): 1469-8137 [Available at www.newphytologist.com].

[24] Gorte, R. W. (2009). Carbon Sequestration in Forests. Congressional Research Service. CRS Report for Congress, (Eggleston, H. S, Buendia, L. and Miwa, K. eds). Prepared for Members and Committees of Congress. Greenhouse Gas Inventories Programme. CRS Publishing, USA, Pp. 1-23.

[25] Adugna Feyissa, Teshome Soromessa, Mekuria Argaw. (2013). Forest Carbon Stocks and Variations along Altitudinal Gradients in Egdu Forest: Implications of Managing Forests for Climate Change Mitigation. J. STAR 2(4): 40-46.

[26] Getu Shiferaw. (2012). Carbon stocks in different pools in natural and plantation forests of Chilimo, central highland of Ethiopia. Unpublished M.Sc thesis, Addis Ababa University. Addis Ababa.

[27] Mesfin Sahile. (2011). Estimating and Mapping of Carbon Stocks based on Remote Sensing, GIS and Ground Survey in the MenageshaSuba State Forest.M.Sc. Thesis, Addis Ababa University, Addis Ababa.

[28] Muluken Nega Bazezew, Teshome Soromessa, Eyale Bayable. Above- and Below-Ground Reserved Carbon in Danaba Community Forest of Oromia Region, Ethiopia: Implications for $\mathrm{CO}_{2}$ Emission Balance. American Journal of Environmental Protection. Vol. 4, No.2, 2015, pp. 75-82. doi: 10.11648/j.ajep.20150402.11.

[29] Sharma, C. M., Suyal, S., Gairolia, S., Ghildiyal, S. K., 2009. Species richness and diversity along an altitudinal gradient in moist temperate forest of GarhwalHimalaya. J.American science. 5(5). 119-128.

[30] Moser, G., Hertel, D. and Leuschner, C. (2007). Altitudinal change in LAI and stand leaf biomass in tropical montane forests a transect study in Ecuador and a pan-tropical meta analysis. $J$. Ecosystems. 10: 924-935.

[31] Sheikh, M. A., Kumar, S. and Kumar, M. (2012). Above and below ground organic carbon stocks in a sub-tropical Pinusroxburghii Sargent forest of the Garhwal Himalayas, Beijing Forestry University and Springer-Verlag Berlin Heidelberg.

[32] Zhu, B., Wang, X., Fang, J., Piao, S., Shen, H., Zhao, S., and Peng, C. (2010). Altitudinal Changes in Carbon Storage of Temperate Forests on Mt. Changbai, Northeast China, J. Plant Resource. 123(4): 439-450.

[33] Gairola, S., Sharma, C. M., Ghildiyal, S. K. and Suyal, S. (2011). Live tree biomass and carbon variation along an altitudinal gradient in moist temperate valley slopes of the Garhwal Himalaya (India). J. Current science. 100(12): 1862-1870.

[34] Tibebu Yelemfrhat Simegn, Teshome Soromessa. Carbon Stock Variations Along Altitudinal and Slope Gradient in the Forest Belt of Simen Mountains National Park, Ethiopia. American Journal of Environmental Protection. Vol. 4, No. 4 , 2015, pp. 199-201. doi: 10.11648/j.ajep.20150404.15. 
[35] Mwakisunga, B. and Majule, A. E. (2012). The influence of altitude and management on carbon stock quantities in rungwe forest, southern highland of Tanzania. Open Journal of Ecology. 2(4): 214- 221.

[36] Tsui, C., Chena, Z. and Hsieh, C. (2004). Relationships between soil properties and slope position in a lowland rain forest of southern Taiwan. J. Geoderma. 123: 131-142. [Available online at www.Science direct.com].

[37] Griffiths, R. P. Madritch, M. D. Swanson, A. K. (2009). The effects of topography on forest soil characteristics in the Oregon Cascade Mountains (USA): Implications for the effects of climate change on soil properties. J. Forest Ecology and Management. 257: 1-7.

[38] Sheikh, M. A., Kumar, M. and Bussmann, R. W. (2009). Altitudinal variation in soil organic carbon stock in coniferous subtropical and broadleaf temperate forests in Garhwal Himalaya. J. Carbon Balance and Management, Biomed central 4(6): 1-6. 